\title{
SERVITE
}

\section{Penyuluhan Literasi Media tentang Dampak Pornografi bagi Remaja Badui Luar di Desa Kanekes, Lebak - Banten}

\author{
Nur Kholisoh \\ Universitas Mercu Buana Jakarta - Indonesia
}

\begin{abstract}
ABSTRAK
Selama ini banyak pihak yang belum peduli memberi informasi sehat tentang seks kepada anak dan remaja. Tidak heran kejahatan seksual yang dilakukan oleh remaja dan anak di bawah umur semakin marak. Sementara itu, penyebaran situs pornografi banyak terjadi di media sosial. Media sosial merupakan media online berbasis teknologi informasi. Teknologi adalah salah satu media yang dapat membantu manusia untuk dapat hidup lebih baik, namun jika teknologi disalahgunakan maka dapat menghancurkan penggunanya. Teknologi juga telah digunakan oleh masyarakat Kanekes Luar, Badui. Melalui teknologi mereka mengenal dunia luar meski tidak mengenyam pendidikan formal. Masyarakat Kanekes tidak mengenal sekolah, karena pendidikan formal berlawanan dengan adatistiadat mereka. Akibatnya, mayoritas warga Kanekes tidak dapat membaca atau menulis. Kendati demikian, melalui teknologi yang mereka gunakan, mereka dapat mengakses berbagai informasi melalui media sosial, terutama di kalangan remaja. Penggunaan media sosial di kalangan remaja masyarakat Kanekes Luar perlu disikapi dengan bijak, mengingat konten yang ada di media sosial tidak selalu bermuatan postif, seperti muatan yang mengandung unsur pornografi. Oleh karena itu, literasi media menjadi hal yang sangat penting dalam upaya menyadarkan remaja Kanekes tentang bahaya pornografi terutama yang ada di media sosial YouTube.
\end{abstract}

Kata kunci: literasi media; dampak media; pornografi; remaja; media sosial.

\section{Media Literacy on the Impact of Pornography on Adolescents in Kanekes Village, Lebak - Banten}

\begin{abstract}
Many parties have not cared about providing healthy information about sex to children and adolescents. It is not surprising that sexual crimes committed by adolescents and minors are increasing. Meanwhile, the spread of pornographic sites is prevalent on social media. Social media is an online media based on information technology. Technology is one of the media that can help humans to better lives, but if technology is misused it can destroy its users. Technology has also been used by the Kanekes Luar, Badui community. Through technology they get to know the outside world even though they have not received formal education. The Kanekes community does not know schools, because formal education is against their customs. As a result, the majority of Kanekes residents cannot read or write. However, through the technology they use, they can access various information through social media, especially among teenagers. The use of social media among teenagers in the Kanekes Luar community needs to be addressed wisely, considering that the content on social media is not always positive, such as content that contains pornographic elements. Therefore, media literacy is very
\end{abstract}


important in an effort to make Kanekes teenagers aware of the dangers of pornography, especially on YouTube social media.

Keywords: media literacy; media impact; pornography; adolescents; social media

\section{PENDAHULUAN}

Kanekes adalah desa yang terletak di Kecamatan Leuwidamar, Kabupaten Lebak, Banten. Desa yang terletak 38 km dari Kota Rangkasbitung ini dihuni oleh suku Badui yang menyebut diri mereka sebagai "urang Kanekes". Mereka merupakan kelompok etnis masyarakat adat suku Banten di wilayah Kabupaten Lebak. Populasi suku ini sekitar 26.000 orang, dan merupakan salah satu suku yang mengisolasi diri dari dunia luar. Selain itu mereka tabu didokumentasikan, khususnya penduduk wilayah Badui Dalam.

Sebutan "Badui" merupakan sebutan yang diberikan oleh penduduk luar kepada kelompok tersebut, berawal dari sebutan para peneliti Belanda yang agaknya mempersamakan mereka dengan kelompok Arab Badawi yang berpindah-pindah (nomaden). Kemungkinan lain adalah adanya Sungai Badui dan Gunung Badui di bagian utara wilayah tersebut. Mereka sendiri lebih suka menyebut diri sebagai urang Kanekes (orang Kanekes) sesuai dengan nama wilayah mereka. Sebutan itu mengacu kepada nama kampung, seperti Urang Cibeo (Garna, 1993).

Wilayah Kanekes secara geografis terletak pada koordinat $6^{\circ} 27^{\prime} 27^{\prime \prime}-6^{\circ} 30^{\prime} 0^{\prime \prime}$ LS dan $108^{\circ} 3^{\prime} 9^{\prime \prime}$ - 106 ${ }^{\circ}{ }^{\prime} 55^{\prime \prime}$ BT (Permana, 2001). Mereka bermukim di kaki pegunungan Kendeng di Desa Kanekes, Kecamatan Leuwidamar, Kabupaten Lebak, Rangkasbitung, Banten, berjarak sekitar $40 \mathrm{~km}$ dari kota Rangkasbitung. Wilayah yang merupakan bagian dari Pegunungan Kendeng dengan ketinggian 300-600 m di atas permukaan laut (DPL) tersebut mempunyai topografi berbukit dan bergelombang dengan kemiringan tanah rata-rata mencapai $45 \%$, yang merupakan tanah vulkanik (di bagian utara), tanah endapan (di bagian tengah), dan tanah campuran (di bagian selatan). Suhu rata-rata di sana adalah $20^{\circ} \mathrm{C}$.

Orang Kanekes memiliki hubungan sejarah dengan orang Sunda. Penampilan fisik dan bahasa mereka mirip dengan orang-orang Sunda pada umumnya. Satu-satunya perbedaan adalah kepercayaan dan cara hidup mereka. Orang Kanekes menutup diri dari pengaruh dunia luar dan secara ketat menjaga cara hidup mereka yang tradisional, sedangkan orang Sunda lebih terbuka dari pengaruh asing dan mayoritas beragama Islam. Masyarakat Kanekes secara umum terbagi dalam tiga kelompok yaitu tangtu, panamping, dan dangka (Permana, 2001).

Kelompok tangtu adalah kelompok yang dikenal sebagai Kanekes Dalam (Badui Dalam), yang paling ketat mengikuti adat, yaitu warga yang tinggal di tiga kampung: Cibeo, Cikertawana, dan Cikeusik. Ciri khas orang Kanekes Dalam adalah pakaiannya berwarna putih alami dan 
biru tua (warna tarum) serta memakai ikat kepala putih. Mereka dilarang secara adat untuk bertemu dengan orang asing.

Kanekes Dalam adalah bagian dari keseluruhan orang Kanekes. Tidak seperti Kanekes Luar, warga Kanekes Dalam masih memegang teguh adat-istiadat nenek moyang mereka. Sebagian peraturan yang dianut oleh suku Kanekes Dalam antara lain: (1) tidak diperkenankan menggunakan kendaraan untuk sarana transportasi; (2) tidak diperkenankan menggunakan alas kaki; (3) pintu rumah harus menghadap ke utara/selatan (kecuali rumah sang Pu'un atau ketua adat); (4) larangan menggunakan alat elektronik (teknologi); (5) menggunakan kain berwarna hitam/putih sebagai pakaian yang ditenun dan dijahit sendiri serta tidak diperbolehkan menggunakan pakaian modern.

Kelompok masyarakat kedua, disebut panamping adalah mereka yang dikenal sebagai Kanekes Luar (Badui Luar), tinggal di berbagai kampung yang tersebar mengelilingi wilayah Kanekes Dalam, seperti Cikadu, Kaduketuk, Kadukolot, Gajeboh, Cisagu, dan lain sebagainya. Masyarakat Kanekes Luar berciri khas mengenakan pakaian dan ikat kepala berwarna biru gelap (warna tarum).

Warga Kanekes Luar merupakan orang-orang yang telah keluar dari adat dan wilayah Kanekes Dalam. Ada beberapa hal yang menyebabkan dikeluarkannya warga Kanekes Dalam ke Kanekes Luar: (1) mereka telah melanggar adat masyarakat Kanekes Dalam; (2) berkeinginan untuk keluar dari Kanekes Dalam; (3) menikah dengan anggota Kanekes Luar.

Selain itu, masyarakat atau orang Kanekes Luar mempunyai ciri-ciri khusus yang berbeda dengan masyarakat Kanekes dalam, yaitu: (1) telah mengenal teknologi, seperti peralatan elektronik; (2) proses pembangunan rumah penduduk Kanekes Luar telah menggunakan alatalat bantu, seperti gergaji, palu, paku, dll, yang sebelumnya dilarang oleh adat Kanekes Dalam; (3) menggunakan pakaian adat dengan warna hitam atau biru tua (untuk laki-laki), menandakan mereka tidak suci. Kadang menggunakan pakaian modern seperti kaos oblong dan celana jeans; (4) menggunakan peralatan rumah tangga modern, seperti kasur, bantal, piring gelas kaca dan plastik; (5) tinggal di luar wilayah Kanekes Dalam; (6) sebagian di antara mereka telah terpengaruh dan berpindah agama menjadi seorang muslim.

Kanekes Dalam dan Kanekes Luar berada di wilayah Kanekes, sedangkan "Kanekes Dangka" tinggal di luar wilayah Kanekes yang saat ini tersisa dua kampung: Padawaras (Cibengkung) dan Sirahdayeuh (Cihandam). Kampung Dangka tersebut berfungsi semacam buffer zone atas pengaruh dari luar (Permana, 2001).

Menurut kepercayaan yang mereka anut, orang Kanekes merupakan keturunan Batara Cikal, salah satu dari tujuh dewa atau batara yang diutus ke bumi. Asal usul tersebut sering pula dihubungkan dengan Nabi Adam sebagai nenek moyang pertama. Menurut kepercayaan 
mereka, Adam dan keturunannya, termasuk warga Kanekes mempunyai tugas bertapa atau asketik (mandita) untuk menjaga harmoni dunia.

Kepercayaan masyarakat Kanekes yang disebut Sunda Wiwitan yakni ajaran leluhur turun temurun yang berakar pada penghormatan kepada karuhun atau arwah leluhur dan pemujaan kepada roh kekuatan alam (animisme). Meskipun sebagian besar aspek ajaran ini adalah asli tradisi turun-temurun, pada perkembangan selanjutnya ajaran leluhur ini juga sedikit dipengaruhi oleh beberapa aspek ajaran Hindu, Buddha, dan Islam.

Bentuk penghormatan kepada roh kekuatan alam ini diwujudkan melalui sikap menjaga dan melestarikan alam; yaitu merawat alam sekitar (gunung, bukit, lembah, hutan, kebun, mata air, sungai, dan segala ekosistem di dalamnya), serta memberikan penghargaan setinggitingginya kepada alam, dengan cara merawat dan menjaga hutan larangan sebagai bagian dalam upaya menjaga keseimbangan alam semesta. Inti kepercayaan tersebut ditunjukkan dengan adanya pikukuh atau ketentuan adat mutlak yang dianut dalam kehidupan sehari-hari orang Kanekes (Garna, 1993). Isi terpenting dari pikukuh Kanekes adalah konsep "tanpa perubahan apa pun", atau perubahan sesedikit mungkin.

Masyarakat Kanekes mengenal dua sistem pemerintahan, yaitu sistem nasional, yang mengikuti aturan negara Indonesia, dan sistem adat yang mengikuti adat istiadat yang dipercaya masyarakat. Kedua sistem tersebut digabung atau diakulturasikan sedemikian rupa sehingga tidak terjadi benturan. Secara nasional, penduduk Kanekes dipimpin oleh kepala desa yang disebut sebagai jaro pamarentah, yang ada di bawah camat, sedangkan secara adat tunduk pada pimpinan adat Kanekes yang tertinggi, yaitu "Pu'un".

Pemimpin adat tertinggi dalam masyarakat Kanekes adalah "Pu'un" yang ada di tiga kampung tangtu. Jabatan tersebut berlangsung turun-temurun, namun tidak otomatis dari bapak ke anak, melainkan dapat juga kerabat lainnya. Jangka waktu jabatan Pu'un tidak ditentukan, hanya berdasarkan pada kemampuan seseorang memegang jabatan tersebut.

Masyarakat Kanekes (terutama Kanekes Luar) yang sampai sekarang ini ketat mengikuti adatistiadat, bukan masyarakat terasing, terpencil, ataupun masyarakat yang terisolasi dari perkembangan dunia luar. Berdirinya Kesultanan Banten yang secara otomatis memasukkan Kanekes ke dalam wilayah kekuasaannya pun tidak lepas dari kesadaran mereka. Kendati demikian, dalam bidang pendidikan, masyarakat Kanekes masih jauh tertinggal dibandingkan dengan masyarakat lainnya yang ada di wilayah Banten. Hal ini tidak terlepas dari adat istiadat mereka anut yang memandang pendidikan bukan merupakan hal yang penting.

Di sisi lain, bagi masyarakat Kanekes Luar sudah mengenal teknologi, alat komunikasi termasuk media sosial, sehingga mereka tidak asing menggunakannya. Sayangnya, 
kemampuan mengakses teknologi dan media sosial tidak diimbangi dengan pendidikan dan ilmu pengetahuan, sehingga dapat menimbulklan dampak negatif yang tidak diinginkan.

Melalui teknologi mereka mengenal dunia luar meski tidak mengenyam pendidikan formal. Orang Kanekes tidak mengenal sekolah, karena pendidikan formal berlawanan dengan adatistiadat mereka. Mereka menolak usulan pemerintah untuk membangun fasilitas sekolah di desa-desa mereka. Bahkan hingga hari ini, walaupun sejak era Soeharto pemerintah telah berusaha untuk mengubah cara hidup mereka dan membangun fasilitas sekolah modern di wilayah mereka. Akibatnya, mayoritas orang Kanekes tidak dapat membaca atau menulis. Kendati demikian, melalui teknologi yang mereka gunakan, mereka dapat mengakses berbagai informasi melalui media sosial, terutama di kalangan remaja.

Penggunaan media sosial di kalangan remaja yang ada di masyarakat Kanekes Luar perlu disikapi dengan bijak, mengingat konten yang ada di media sosial tidak selalu bermuatan postif, seperti muatan yang mengandung unsur pornografi. Oleh karena itu, literasi media menjadi hal yang sangat penting dalam upaya menyadarkan remaja yang ada di masyarakat Kanekes tentang bahaya pornografi, terutama yang ada di media sosial YouTube.

Ancaman atas bahaya dan dampak negatif dari media sosial terutama YouTube, antara lain adalah masalah pornografi. Hal ini dapat dicegah dengan melakukan tindakan preventif melalui kegiatan literasi media. Literasi media merupakan kemampuan seseorang untuk memahami, menganalisis, dan mendekonstruksi pencitraan media. Kemampuan untuk melakukan hal ini ditujukan agar pemirsa sebagai konsumen media (termasuk anak-anak dan reamaja) menjadi sadar (melek) tentang cara media dikonstruksi (dibuat) dan diakses.

Kegiatan ini bertujuan agar para remaja di Desa Kanekes, Kabupaten Leuwidamar, Provinsi Banten, memiliki kemampuan untuk memahami, menganalisis, dan mengkritisi konten yang ada di media sosial YouTube sehingga terhindar dari dampak negatif pornografi yang banyak terdapat di media sosial YouTube.

Kegiatan literasi media ini merupakan program kegiatan yang ditujukan kepada para remaja yang ada di masyarakat Kanekes, khususnya Kanekes Luar yang memang sudah lebih terbuka dan mengenal teknologi. Menurut psikologi, remaja adalah suatu periode transisi dari masa awal anak anak hingga masa awal dewasa, yang dimasuki pada usia kira kira 10 hingga 12 tahun dan berakhir pada usia 18 tahun hingga 22 tahun.

Masa remaja adalah masa peralihan dari masa anak-anak dengan masa dewasa dengan rentang usia antara 12-22 tahun, dimana pada masa tersebut terjadi proses pematangan baik itu pematangan fisik, maupun psikologis. Untuk itu, rentang waktu usia remaja ini biasanya dibedakan atas tiga, yaitu: masa remaja awal, 12 - 15 tahun, masa remaja pertengahan, 15 18 tahun, dan masa remaja akhir, 18-21 tahun 
Sementara itu, Monks, Knoers, dan Haditono membedakan masa remaja menjadi empat bagian, yaitu masa pra-remaja 10 - 12 tahun, masa remaja awal 12 - 15 tahun, masa remaja pertengahan 15 - 18 tahun, dan masa remaja akhir 18 - 21 tahun (Deswita, 2006:192). Berdasarakan berbagai pertimbangan, pendapat para ahli dan melihat situasi kondisi yang ada di masyarakat Kanekes Banten saat ini, maka remaja yang dimaksudkan dalam kegiatan ini adalah mereka yang berusia antara 12 tahun sampai dengan 22 tahun.

Setelah mengikuti kegiatan literasi media ini, diharapkan para remaja di Desa Kanekes Banten, memiliki kemampuan untuk memahami, menganalisis, dan mengkritisi konten yang ada di media sosial YouTube agar mereka terhindar dari dampak negatif pornografi yang banyak terdapat di media sosial YouTube.

Selain itu, dengan mempelajari literasi media, menjadikan remaja di Desa Kanekes sebagai individu yang "melek media". Artinya, pribadi yang paham, berpengetahuan luas, mampu menganalisis, menilai, dan mampu berpendapat secara kritis atas informasi atau pesan media yang didapat, sehingga dapat mengambil sikap atas sebuah isu secara bijak dan tidak mudah terbawa arus dan tergiring opininya menuju hal yang bersifat negatif.

Internet sudah menjadi bagian tak terpisahkan dari kehidupan modern. Melarang remaja berinternet seperti melarang anak memakai energi listrik dan kembali ke zaman batu. Hendaknya jawaban tidak berorientasi kembali ke masa lalu atau anti-modernisasi. Lalu pertanyaan yang perlu dijawab juga: Bagaimana melindungi remaja dari pornografi di media sosial terutama YouTube?

Dalam mengatasi masalah hal ini, peran orang tua dan lingkungan sangat penting. Masih banyak orang tua yang belum menyadari bahaya dan dampak negatif dari media sosial, terutama yang terkait dengan pornografi. Berbagai bahaya di Internet dan masalah kecanduan Internet bukan tidak dapat diatasi. Dengan mengetahui dampak negatif dari Internet, orang-tua dapat melindungi buah hatinya.

Maraknya pornografi di media sosial YouTube menjadi tontonan rutin para anak muda dan remaja. Fenomena ini juga muncul di kalangan remaja di Desa Kanekes Luar yang sudah lebih mengenal teknologi di bandingkan dengan remaja di suku Badui lainnya. Untuk menghindari dan mengantisipasi dampak negatif dari pornografi di media sosial YouTube, maka perlu dilakukan kegiatan literasi media di kalangan remaja di Desa Kanekes.

Ada beberapa hal yang akan disampaikan dalam kegiatan literasi media di kalangan remaja di Desa Kanekes untuk menghindari dan mengantisipasi dampak negatif dari pornografi yang ada di media sosial YouTube, antara lain: (1) lebih memilah tontonan yang ada, terutama di YouTube karena beragamnya konten yang bersifat positif maupun negatif; (2) diharapkan tidak mudah mencoba tren-tren yang ada di YouTube, apalagi jika tren itu tidak sesuai dengan 
norma di masyarakat; (3) diharapkan tidak menutup kemungkinan memanfaatkan YouTube secara positif untuk mencari informasi, sarana berkreasi dan mengembangkan kreatifitas.

\section{METODE PELAKSANAAN}

Khalayak sasaran dari kegiatan literasi media di kalangan remaja preventif terhadap dampak pornografi pada Media Sosial YouTube ini adalah para remaja yang ada di Desa Kanekes, Kabupaten Leuwidamar, Propinsi Banten. Adapun remaja yang dimaksudkan dalam kegiatan ini adalah mereka yang berusia antara 12 tahun sampai dengan 22 tahun.

Kegiatan ini merupakan kegiatan literasi media yang meliputi tujuh kecakapan yaitu: Analysis (berkaitan dengan kemampuan memahami isi dan konten serta membongkar dan mengkaji suatu pesan atau informasi dari sebuah media); evaluation (mampu memberikan penilaian atas suatu pesan informasi yang media sampaikan); Grouping (mampu mengelompokkan berbagai informasi yang kita peroleh dari suatu media dalam sebuah persamaan dan perbedaan tertentu); Induction (kemampuan menganalisis dan mengkaji suatu informasi dari yang bersifat khusus dalam lingkup kecil menuju pada yang bersifat umum secara menyeluruh);

Deduction (kemampuan menganalisis dan mengkaji informasi yang bersifat umum kemudian menjabarkanya menjadi informasi yang bersifat khusus); Synthesis (kemampuan untuk merangkai kembali sebuah pesan atau informasi dari suatu media menjadi sebuah pesan dalam struktur baru yang berbeda dari sebelumnya), dan Abstracting (kemampuan dan kecakapan yang lengkap, mulai dari menganalisis, mendeskripsikan, mencari titik poin permasalahan atau isu sampai kepada meringkas pesan dan menyajikanya kembali dengan bahasa yang lebih mudah dimengerti).

Pelatihan ini menggunakan beberapa cara atau metode, yaitu diskusi, presentasi dan ceramah. Diskusi dalam bentuk kelompok (focus group discussion/FGD) dilakukan dengan membagi peserta ke dalam beberapa kelompok kecil untuk mendiskusikan tema atau isu yang dikemukakan oleh narasumber, terutama yang terkait dengan dampak negatif pornogafi di media sosial, khususnya YouTube. Setelah selesai didiskusikan, perwakilan masing-masing kelompok mempresentasikan hasil diskusi kelompoknya secara bergantian yang kemudian direspon atau ditanggapi oleh kelompok diskusi yang lain.

Selanjutnya, hasil dari FGD dibahas oleh narasumber dengan memberikan pengarahan dan penjelasan melalui teknik ceramah. Dalam pembahasan ini, narasumber menyampaikan materi utama tentang pornografi dan dampak negatif dari pornografi di media sosial, khususnya media YouTube. 
Selain itu, juga membahas tentang pemberdayaan sikap orang tua untuk mencegah (preventif) terhadap dampak negatif pornografi media sosial Youtube. Untuk lebih memperjelas dan memberikan pemahaman yang baik tentang materi yang disampaikan, narasumber memberikan contoh-contoh yang berkaitan pornografi di media sosial.

\section{HASIL DAN PEMBAHASAN}

Pelatihan dilaksanakan pada Senin-Selasa, 8 - 9 Juli 2019 pukul 08.00 sampai dengan 10.00 WIB. Pelatihan dihadiri 10 orang dari 20 orang pengurus Rukun Warga yang diundang dan 15 siswa dari 20 siswa SMA. Pelatihan ini berjalan dengan sukses dan lancar.

Pelatihan dibuka oleh Ketua Program Studi Magister Ilmu Komunikasi, Dr. Ahmad Mulyana, M.Si yang dilanjutkan dengan pemaparan tentang dampak negatif pornografi di media sosial YouTube oleh Dr. Nur Kholisoh, M.Si yang menjelaskan tentang media sosial secara umum seperti Path, Twitter, Instagram, Facebook, YouTube, dan Vlog. Setelah itu, dijelaskan tentang dampak dari media sosial YouTube, baik yang positif maupun negatif.

Sisi positif dari media sosial bisa menjadi kecil dibandingkan dengan sisi negatifnya jika pemakai salah menggunakannya. Ada beberapa dampak negatif dari media sosial, termasuk YouTube antara lain:

(1) Depresi dan ketergantungan. Jejaring media sosial bisa menciptakan depresi bagi penggunanya. Hal ini telah menciptakan suatu penyakit baru seperti facebook depression. Penyakit ini awalnya terlihat sama seperti kecemasan, kelainan psikis, ketergantungan atau kebiasaan buruk lainnya, namun semakin lama akan semakin berbahaya terutama jika penggunanya tidak bisa melepaskan diri dari media social;

(2) Tidak bisa mengontrol diri. Pengguna adiktif media sosial dinilai tidak bisa mengontrol dirinya. Bagi mereka yang mengalami kecenduan akut, bahkan memiliki kontrol diri yang sangat rendah. Menurut para peneliti, pengguna media sosial terlalu peduli dengan citra mereka di media sosial, khususnya harga diri pada teman-teman dekatnya;

(3) Penipuan. Penyalahgunaan media sosial dapat menimbulkan terjadinya penipuan yang cenderung ke arah kriminalitas, seperti pemerkosaan dan kejahatan lainnya yang bisa mengancam jiwa penggunanya. Selain itu, media sosial juga banyak digunakan untuk bisnis prostitusi yang kadangkala korbannya tidak tahu tetapi terperdaya dengan tipu muslihat para pelaku kejahatan yang menggunakan sarana media social;

(4) Penurunan produktifitas dan rasa social. Banyak remaja kecanduan menggunakan media sosial tanpa mengenal waktu sehingga menurunkan produktifitas dan rasa sosial. Sementara 
itu, remaja yang sedang labil apalagi suka bermimpi hidup mewah akan mudah terjerumus dalam kejahatan sosial kaena sudah tidak lagi peduli dengan lingkungan sosialnya.

Ada beberapa cara pencegahan dampak negatif konten media sosial, termasuk YouTube yang dikemukakan oleh Dr. Nur Kholisoh, M.Si, yaitu: Para orang tua harus mengawasi anak-anak remaja dalam kegiatan yang berkaitan dengan internet, terutama penggunaan sosial media. Para orang tua juga harus memperhatikan konsumsi media anak-anak mereka, jangan sampai mengkonsumsi media yang memiliki konten negatif seperti pornografi.

Sosialisasi penggunaan media sosial yang bijak perlu dimiliki orang tua yang diharapkan dapat mencegah siswa SMA dari dampak negatif penggunaan internet. Jika internet digunakan dengan penuh tanggung jawab, sangat memberi manfaat untuk pelajar SMA. Dengan internet, para siswa SMA bisa dengan menyelesaikan tugas sekolah. Para siswa SMA juga harus mengedepankan etika, serta menghindari konten yang bermuatan rasis. Selain itu, jangan memberikan data pribadi di sosial media, karena hal tersebut dapat menjadi pemicu tindak kriminal, apalagi mengungah konten video atau foto pelanggaran asusila.

Selama kegiatan berlangsung, para pengurus RW dan para siswa SMA di wilayah Kelurahan Meruya Selatan antusias mendengarkan dan mengikuti penjelasan dan paparan yang disampaikan. Hal ini terlihat dari aktifitas mereka pada saat sesi tanya jawab.

Para peserta dengan sigap mengajukan pertanyaan, mulai dari pertanyaan tentang alasan mengapa Indonesia mendudukui peringkat kedua di dunia sebagai negara pengakses pornografi terbanyak di dunia, hingga kemungkinan di Indonesia didirikan sekolah seperti Oxbow Academy yang ada di Utah Amerika Serikat.

\section{SIMPULAN}

Media sosial YouTube memiliki dampak positif dan negatif, tetapi dampak negatifnya lebih kuat jika tidak dipergunakan secara bijaksana. Ada beberpa dampak negatif media sosial YouTube, antara lain: kesehatan fisik dan psikologis sering terganggu, jarang bergaul dengan lingkungan, waktu bersama keluarga menjadi berkurang, sering lupa mengurus diri, depresi dan ketergantungan, serta penurunan produktifitas dan rasa social.

Para peserta pelatihan yang terdiri dari para Ketua RW (Rukun Warga) dan Ketua RT (Rukun Tetangga) serta siswa-siswi SMA dapat menerima penjelasan dengan baik dan memahami materi yang disampaikan. Setelah diberikan penjelasan dan pelatihan, para peserta menjadi lebih fokus pada hal-hal yang positif dari media sosial YouTube, dan berupaya untuk lebih bijak dalam menyikapi bahaya pornografi di media sosial YouTube. 


\section{DAFTAR PUSTAKA}

Arifin, Anwar. (1998) Ilmu Komunikasi: sebuah Pengantar Ringkas, Rajawali Press, Jakarta Devito, J.A, (1997) Komunikasi Antar Manusia. Jakarta: Professional Books

Fahrudin, A. (1994). Pemberdayaan, Partisipasi dan Penguatan Kapasitas Masyarakat. Bandung: Humaniora.

Lord, J., Peggy, H. (1993). E Process of Empowerment: Implications for theory and Practice, Canadian Journal of Community Mental Health, 12: 1

Mc. Quail., Windhal, D.S. (1996) Communication Models, Longman Inc, USA

Mulyana, D. (2000) Ilmu Komunikasi suatu Pengantar, Bandung: Remaja Rosdakarya

Paul, R. W, J. Don, F. (2000) Komunikasi Organisasi, Bandung: Remaja Rosdakarya.

Sandjaja, S.D. (1993) Pengantar Komunikasi, Jakarta: Univeristas Terbuka

Sulistiyani, A.T, et,al. (2017) Proses Pemberdayaan Masyarakat Desa Sitimulyo, Kecamatan Piyungan, Kabupaten Bantul dalam Pembentukan Kelompok Pengelola Sampah Mandiri, Indonesian Journal of Community Engagement, 2(02).

Wilonoyudho, S. (2009). Model Pemberdayaan Masyarakat dalam Pengendalian Banjir yang Berwawasan Lingkungan di Semarang, Jurnal Manusia dan Lingkungan, 16(2). 